\title{
RECONSTRUCTION OF CASPIAN SEA-LEVEL FLUCTUATIONS: RADIOCARBON DATING COASTAL AND BOTTOM DEPOSITS
}

\author{
YU. A. KARPYTCHEV
}

Isotope Laboratory, Institute of Water Problems, Russian Academy of Sciences, 10 Novaya Basmannaya, Moscow 107078 Russia

\begin{abstract}
Owing to the large basin area of the Caspian Sea, fluctuations in its level reflect climatic changes in the northern hemisphere. To reconstruct these fluctuations, I collected mollusk shells, plant debris, carbonates and organic matter samples for ${ }^{14} \mathrm{C}$ dating from deposits of ancient salt marshes, depressions and bars formed during significant sea-level decline. I studied the impact of eolian sedimentation via parallel dating of carbonates and other materials. The data demonstrate that sea level rises during periods of cooling and falls during warming periods; this is true for both long-term (2-2.5 ka) and short-term climatic changes.
\end{abstract}

\section{INTRODUCTION}

Here I investigate Caspian Sea-level fluctuations to study the impact of climate on global water circulation. Different techniques have enabled us to identify three transgression stages in the evolution of the Caspian Sea over the past 50-70 ka: Lower Khvalyn, Higher Khvalyn and Novocaspian periods. These stages are interrupted by the Mangyshlak and Yenotayev regressions. ${ }^{14} \mathrm{C}$ dating allows the approximate determination of the successive stages. Typically, ancient longshore bars and terraces were studied, from which we determined both the age and elevations of corresponding shorelines. However, we observed significant discrepancies related to incorrect age determination. Two factors caused these errors in the dating of longshore bars from shells: 1) redeposition of sediment material and its "rejuvenation"; and 2) exposure of shells to atmospheric $\mathrm{CO}_{2}$ and to bicarbonates dissolved in water.

Lagoons having limited exchange with the sea, and bay shores with minimal slope are accurate recorders of sea-level fluctuations. Minimum mixing of deposits, which can be expected under such conditions, enables determination of sediment ages from shells, carbonates and organic matter, and even from plant debris. This approach to dating carbonate-containing material allows us to reconstruct marine sedimentation more reliably.

\section{METHODS}

The east coast of the Caspian Sea is most suitable for reconstructing sea-level fluctuations. Its limestone outcrops promote favorable conditions for the formation of lagoons and depressions; the absence of river waters and vegetation along the coastline enhances the reliability of dating with the use of carbonates and organic matter. Figure 1 shows sampling locations.

Deposits of the Agrakhan Spit on the west coast are in elongated sections on the banks of a trench that connects Agrakhan Bay with the sea and shore terrace north of Sulak. The choice of sampling areas along the eastern coast (Solonchak near Okarem, Ashchi-Sor depression, the coast of Kochak Bay) was prompted by their different elevations. To determine the periods of regression stages, one core was taken in the Krasnovodsk Bay (Station 127) and three cores at the eastern shelf (Stations 4-, 5- and 10-86) where ancient shorelines are distinct on the sea-bottom surface.

Samples of different carbonate materials were collected throughout each section. Sample pretreatment and benzene synthesis were performed according to Karpytchev (1987). ${ }^{14} \mathrm{C}$ was measured by liquid scintillation counting in a two-channel unit with three detectors, each with 


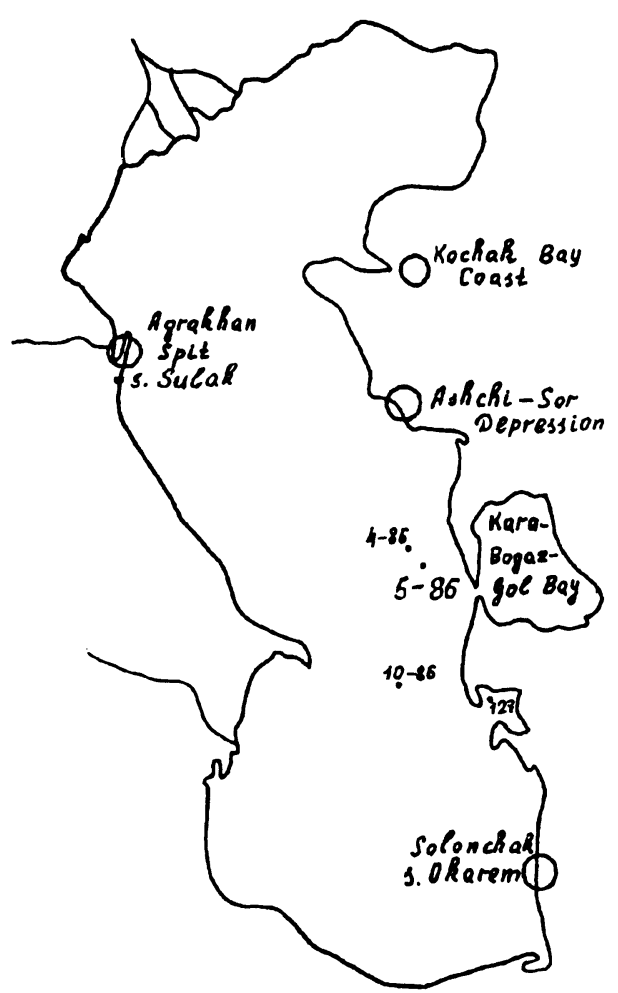

Fig. 1. Sample locations for ${ }^{14} \mathrm{C}$ dating on the Caspian Sea coast; $O=$ shore surface; $\bullet$ = sea bottom background of $1.2,1.6$ and $1.8 \mathrm{cpm}$ at $50 \%$ counting efficiency. Spheroid counting vials had 3.2-, 3.3- and 3.4-ml capacities. A sample was diluted with "dead" carbon $\left(\mathrm{CO}_{2}\right.$ or benzene $)$ if its size was inadequate. Each sample was measured at least twice with different detectors. The error in age determination included, apart from the statistical error, instrument error, determined from multiple measurements of the modern standard and some samples. The minimum error of $\pm 60 \mathrm{yr}$ was determined from measurements over a $48-\mathrm{hr}$ period.

\section{DETERMINING THE AGE OF SEDIMENTATION}

Parallel age measurements from diverse carbonate materials allow us to make conclusions concerning the reliability of dating marine sediments. Plant debris (peat) is considered the most reliable dating material, and serves as a benchmark. Dates of mollusk shells tend to be too young if the shells are exposed to atmospheric $\mathrm{CO}_{2}$. Near river mouths, where mixing of river and sea water occurs, ages can be too old due to decreased ${ }^{14} \mathrm{C}$ concentration in river bicarbonate.

The age of organic matter in bay sediments on the eastern Caspian coast appears to be 100-250 yr older $(150 \pm 50)$ on average than that of plant debris, which may be caused by redeposition. For carbonates, age deviation from the sediment accumulation line (age-to-depth plot based on the datings of plant debris and shells) is greater (Karpytchev 1987). The mean deviation for Solonchak deposits near Okarem (Fig. 1) was $630 \pm$ 80 , for the Ashchi-Sor depression, $560 \pm 120$, and for the Krasnovodsk Bay, $500 \pm 110$, with a mean of $570 \pm 70$. The similarity of these results and their differences from dates of organic matter suggests another cause of old ages-the impact of eolian deposition, which is confirmed by data on bay surface deposits. We calculated age deviations from deposits of various regions and ages, which we use for the entire Novocaspian period. The error of only some individual measurements exceeds $150 \pm 90$ and $570 \pm 250$.

The ${ }^{14} \mathrm{C}$ age of organic matter and carbonates near the bottom of the eastern shelf is $1.1-1.3 \mathrm{ka}$. This value is obtained from extrapolating the sediment accumulation rate and is confirmed by parallel dating of mollusk shells. Concordance of the ages obtained from organic matter and bicarbonates indicates that the only reason for erroneously old ages is redeposition of sediment material.

The Caspian Sea reservoir effect was estimated from seal remains $(345 \pm 65)$ and mollusk shells (384 \pm 59) (Olsson 1983; Arslanov and Tertychnaya 1983). The values of $\delta^{13} \mathrm{C}$ for shells are within -2.5 to $0 \%$ which, after normalizing with respect to ${ }^{13} \mathrm{C}=-25 \%$, yields an age correction of 360-410 yr. Since one quantity has to be added and the other subtracted, no corrections for the reservoir effect were introduced. The value of $\delta^{13} \mathrm{C}$ of peat is assumed close to $-25 \%$. Therefore, 
the age was calculated directly from the ratio of the activities of a specimen and the standard, using the Libby half-life of $5568 \mathrm{yr}$.

Table 1 presents ${ }^{14} \mathrm{C}$ data. Ages of bay sediments determined from organic matter and carbonates are given with the corresponding correction of $150 \pm 90$ and $570 \pm 250 \mathrm{yr}$, respectively. For shelf carbonates, this value is $1200 \pm 100 \mathrm{yr}$. Considering the specific conditions of sediment accumulation, reconstruction of sea-level fluctuations should be made separately for each region. Altitudes given for the slope and terrace sections are above the present-day sea level; depths (negative numbers) given for the cores of depressions are below the sea bottom surface in the corresponding area. (The present-day level of the Caspian Sea is $-28.5 \mathrm{~m}$ asl.)

TABLE 1. Radiocarbon Dates of Caspian Sea Sediments

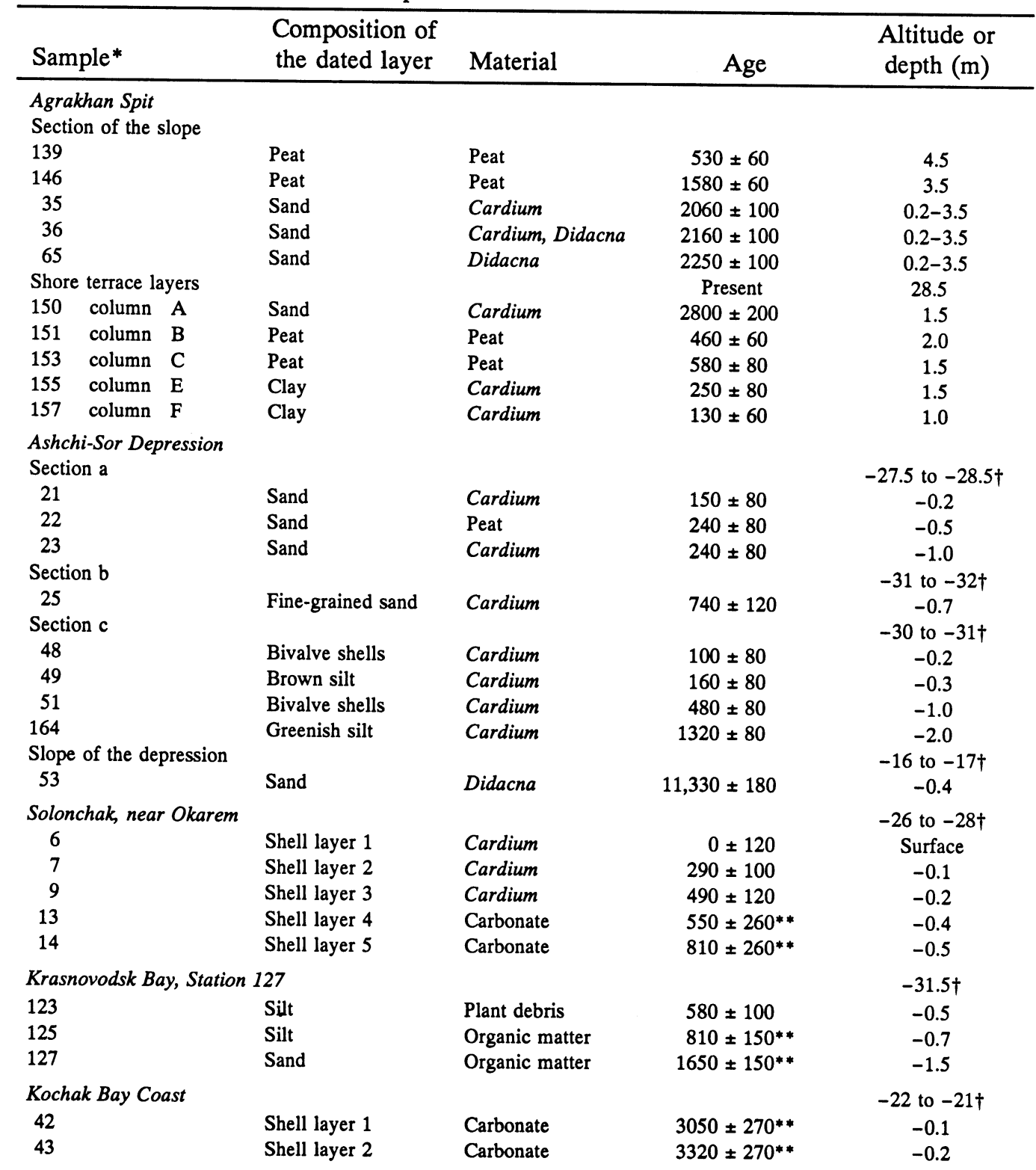


TABLE 1. (Continued)

\begin{tabular}{lllcc}
\hline Sample* & $\begin{array}{c}\text { Composition of } \\
\text { the dated layer }\end{array}$ & Material & \multicolumn{1}{c}{ Age } & $\begin{array}{c}\text { Altitude or } \\
\text { depth (m) }\end{array}$ \\
\hline 172 & Shell layer 3 & Carbonate & $5280 \pm 270^{* *}$ & -0.5 \\
45 & Shell layer 4 & Carbonate & $7630 \pm 270^{* *}$ & -0.9 \\
46 & Blue silt & Carbonate & $8030 \pm 290^{* *}$ & -1.5 \\
Margin Zone of Eastern & Shelf & & & \\
Station 4-86 & & & $-128 \dagger$ \\
208 & Silt, fine aleurite & Dreissena & $6950 \pm 170$ & Surface \\
209 & Shell layer & Dreissena & $11,270 \pm 150$ & -0.7 \\
201 & Shell layer & Detritus & $11,390 \pm 120$ & -0.7 \\
Station 4-86 & & & & -128 \\
217 & Silt, fine aleurite & Carbonate & $6900 \pm 270^{* *}$ & Surface \\
218 & Silt, aleurite-clay & Carbonate & $11,700 \pm 270^{* *}$ & -0.2 \\
202 & Shell layer & Dreissena & $11,530 \pm 180$ & -0.7 \\
205 & Shell layer & Detritus & $11,560 \pm 180$ & -0.7 \\
203 & Silt, aleurite-clay & Detritus & $22,230 \pm 450$ & -1.5 \\
223 & Silt, aleurite-clay & Carbonate & $20,600 \pm 700^{* *}$ & -1.5 \\
Station 10-86 b & & & & $-133 \dagger$ \\
220 & Silt, clay & Carbonate & $6800 \pm 270^{* *}$ & -0.4 \\
210 & Shell layer & Didacna & $9300 \pm 180$ & -1.1 \\
\hline
\end{tabular}

*Index of the Institute of Water Problems

**Age corrected as explained in text

$\dagger$ ¡ottom surface level relative to ocean level

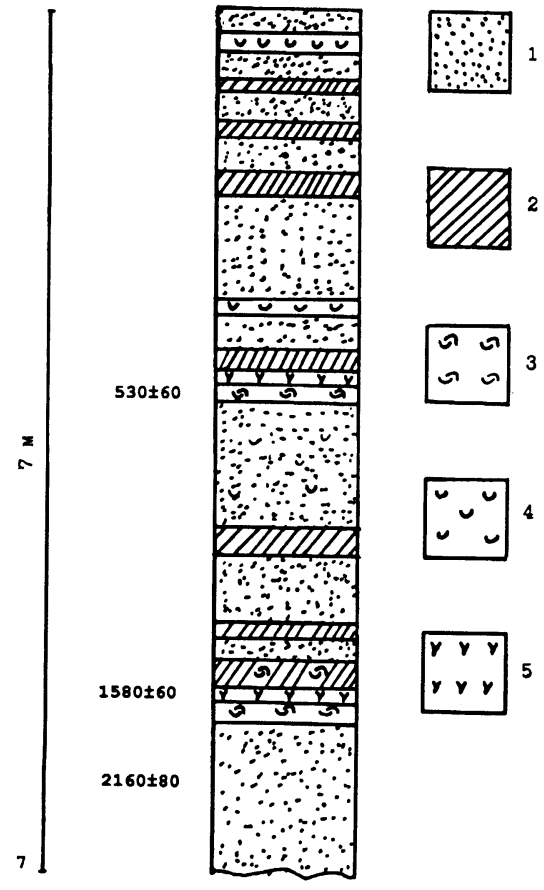

Fig. 2. Slope profile of Agrakhan Spit deposits 1. sand; 2 . sandy loam; 3 . bivalve shells; 4 . singlevalve shells; 5 . peat

\section{DEPOSIT SECTIONS}

\section{Agrakhan Spit}

Figure 2 shows that the spit deposits were formed during three transgressions. Regression stages are indicated as layers of cane peat, formed in shallow areas. The six sections (A-F) of the shore terrace (Fig. 3) reveal the structure of the spit's base. Unlike the slope sections (Fig. 2), only one regression is observed as a layer of either peat or bivalve shells.

Deposits of the first transgression stage are $0.2-3.5 \mathrm{~m}$ thick. Shells were sampled throughout the section and were divided into three subsamples according to size mollusk (Cardium) shells were $\leq 10 \mathrm{~mm}$, Didacna were $\geq 30 \mathrm{~mm}$. The agreement of shell ages (Samples 35, 36, 65 ; Table 1) reflects minimal influence of redeposition processes.

The bottom layer in Section 1 (Table 1) (numbered from the northern tip) consists of coastal terrace deposits. It appears to have formed during the first transgression (Sample 150). Accordingly, the age of the first transgression stage is $2.8-2 \mathrm{ka}$. The Caspian sea level at that time was at least $-25 \mathrm{~m}$. 


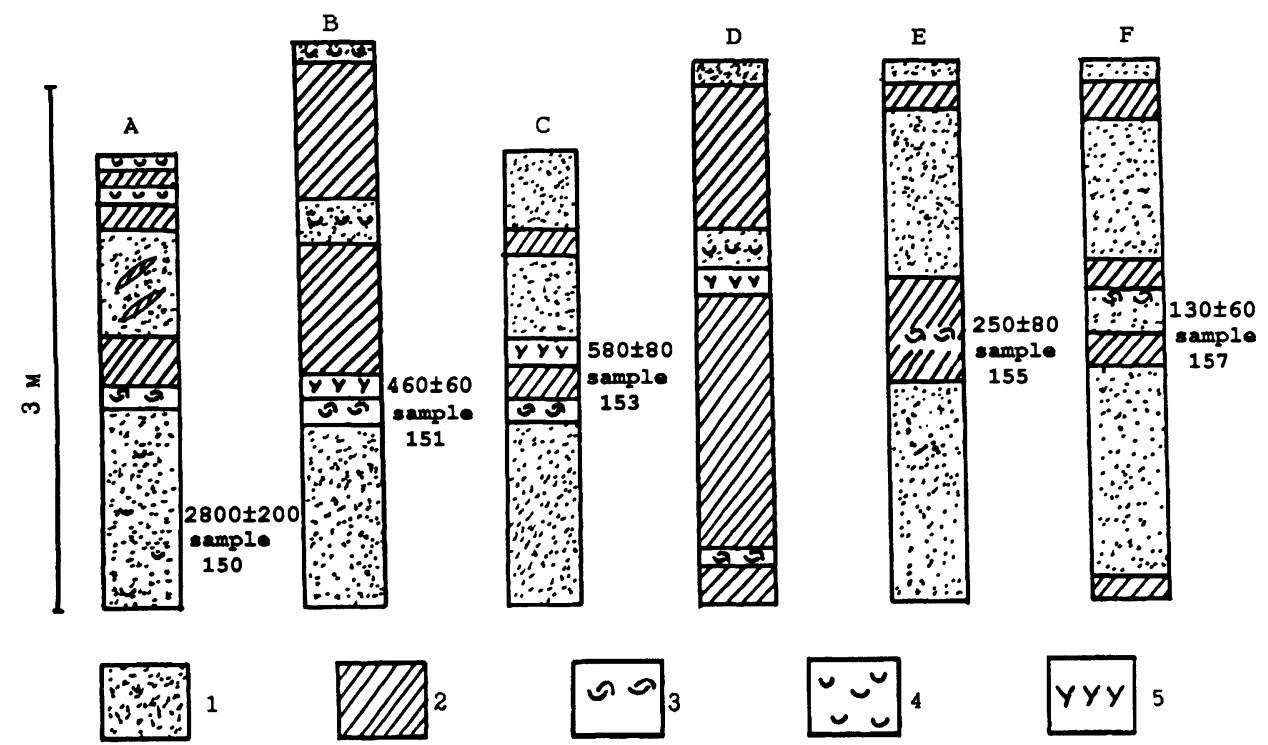

Fig. 3. Columns A-F of the shore terrace deposits. 1. sand; 2. sandy loam; 3. bivalve shells; 4 . single-valve shells; 5. peat

No dates directly determine the age of the second transgression stage, although it is well marked by peat dates-1580 \pm 60 BP (Sample 146) and ca. 460-580 BP (Samples 139, 151, 153)-and reliable archaeological data. The Derbent regression (1000-700 BP) ended with sea level several meters higher than at present (Varuschenko, Varuschenko and Klige 1987). The present level is assumed to be $-28.5 \mathrm{~m}$. Thus, it is certain that the second transgression stage took place at $550-700$, and at $2000-700 \mathrm{BP}$, the sea level was no greater than $0.2 \mathrm{~m}$ above the current level. The second stage was at least $-24 \mathrm{~m}$.

The maximum elevation of the spit deposits is $-21 \mathrm{~m}$. Accounting for onshore and offshore currents and storm overwashes, one can assume that the sea level during the third stage was -22 $\mathrm{m}$. Peat dates indicate that the third transgression stage commenced 460-580 BP. However, it was not marked by any unidirectional characteristics. Deposits of the shore terrace contain layers (Samples 155 and 157 in Layers 4, 5 (Fig. 3)) where bivalve shells mark short-term recession. The age of these layers is $250 \pm 80$ and $130 \pm 60 \mathrm{BP}$ (Samples 155, 157 (Table 1)).

The layer of bivalve shells is useful in reconstructing sea-level fluctuations. Mass death of mollusks occured when the lagoon dried up. Thus, the sea level is properly fixed and the possibility of redeposition is removed. But the dates show that the ages of shells found in various places differ. The age distortion is in the direction of "rejuvenation". This is not true for samples 155 and 157 of the shore terrace, from which shells are considerably larger $(\sim 30 \mathrm{~mm})$ and have thicker walls $(1.0-1.5 \mathrm{~mm})$. Shells in the silt are $\leq 10 \mathrm{~mm}$ and their walls are $0.1-0.2 \mathrm{~mm}$ thick. Dates from the shells of the last transgression stage also reveal appreciable scatter, but in the direction of age overestimation, which is related to the effect of Terek River freshwater. Figure 4 presents these data graphically. 


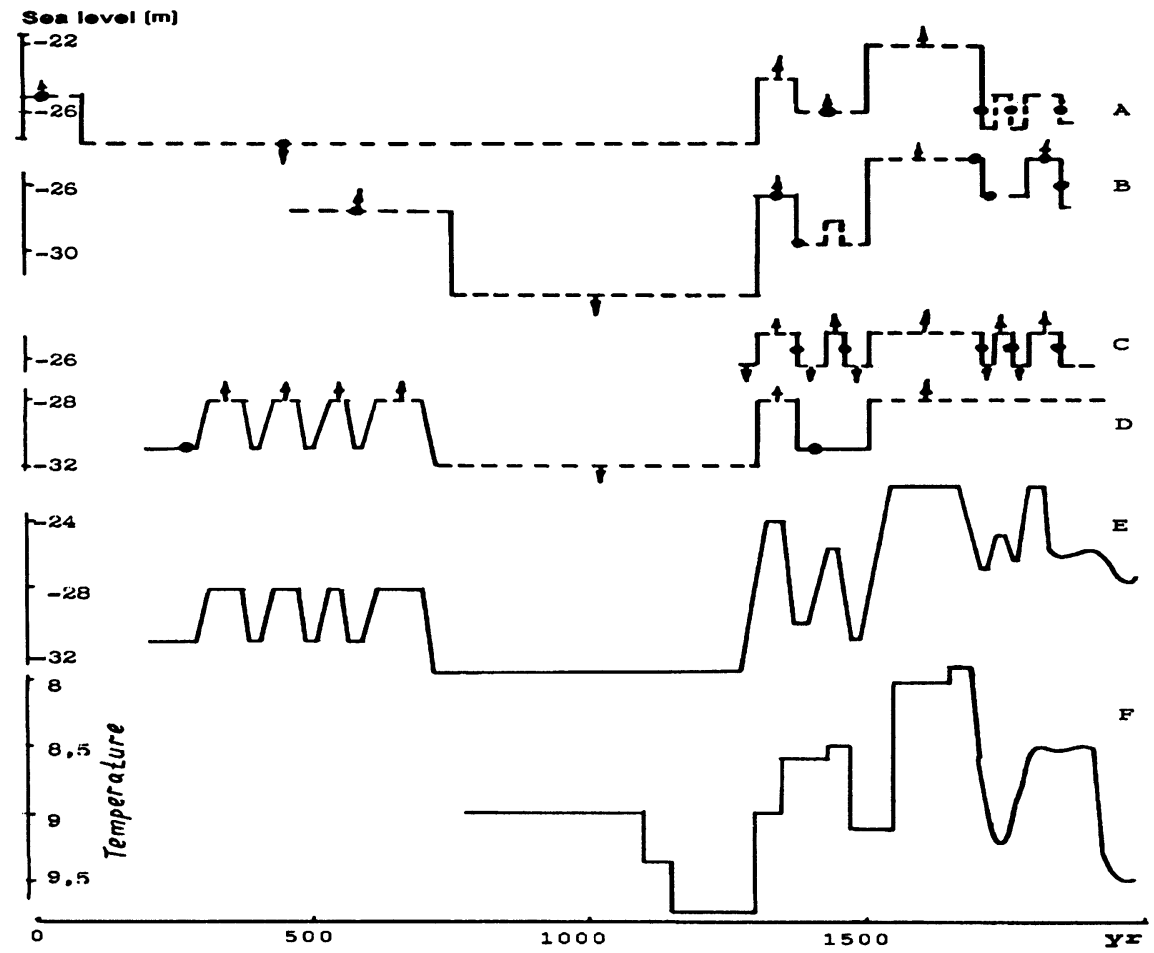

Fig. 4. Reconstruction of Caspian Sea-level fluctuations from dates of deposits. A. Agrakhan Spit; B. Ashchi-Sor depression; C. Okarem; D. Krasnovodsk Bay; E. all of the above areas; F. temperature variations in England; $\bullet={ }^{14} \mathrm{C}$ dates

\section{Ashchi-Sor Depression}

This depression is now a basin separated from the sea by Caspian limestone. For $7 \mathrm{~km}$, the depression is separated from the sea by a sand barrier $0.5-1.0 \mathrm{~km}$ wide and 7-8 $\mathrm{m}$ high (the height of the narrowest part of the barrier is 3-4 m). Since the middle 1800s, the depression has become separated from the Caspian Sea. An almost flat Solonchak bottom is located at 3.0-3.5 m below sea level. In winter, intrusive seawater forms lakes on the base of the depression closer to the sand barrier, which is dry in summer.

The nature of deposition, including paired or unpaired shells, is determined mainly by sea level, sand barrier height and bay morphology. During times of sufficient water exchange with the sea, silt deposits form in deeper areas, with fine-grained sand in shallow areas. Upon death, mollusks separate into individual shells. As sea level falls, the connection between the depression and the sea becomes more distinct. Rising salinity causes mass death of mollusks, and shells are buried in the deposit as paired valves (bivalves).

When the depression was completely cut off from the sea, the basin was fed by occasional seawater intrusion from onshore currents, and later, only by seepage through the barrier and overland flow from the depression slope. Sedimentation was governed by eolian and erosional processes. The deposits turned black, which is typical for stagnant waters. This process continued until the sea level rose again, reaching the height of the barrier. The depression then filled, and in a short time, water exchange recurred. Partial erosion of the barrier and accompanying sea-level rise accelerated this process. 
Samples were collected from three locations: at both edges and at the center of the depression (Sections A, B, C, respectively (Fig. 5)). Each sea-level fluctuation is reflected in strata of greenish or brown silts, sand, bivalve shells, salt, and black silt or mud. Section C, the most representative, vividly displays four sedimentation cycles. There are three cycles of this kind in Section B. A compact layer of vegetation, stems and parts of cane roots, divides the shell-bearing sand bed in Section $\mathrm{A}$, indicating two transgressions separated by a regression stage, during which vegetation developed on the shoal.
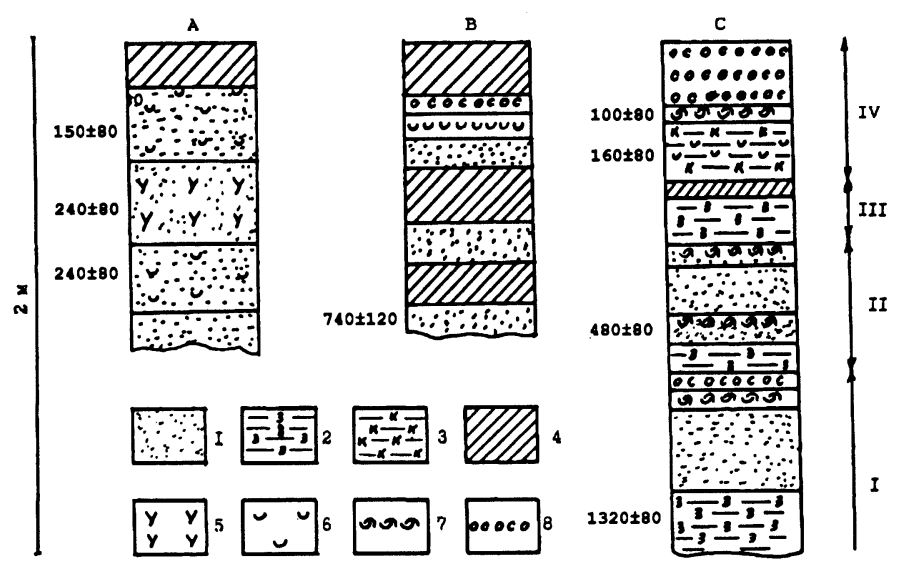

Fig. 5. Composition of the Ashchi-Sor depression. 1. sand; 2 . greenish silt; 3 . brown silt; 4 . black silt; 5 . plant debris; 6. bivalve shells; 7. single-valve shells; 8. salt. I-IV. Cycles of sedimentation

The first and second transgressions dated to $1320 \pm 80$ and $740 \pm 120 \mathrm{yr}$ (Samples 164 and 25 (Table 1)). Sea level was above -27 to $-29 \mathrm{~m}$. The salt layer deposited in the intervening regression indicates that sea level within this period was -32 to $-34 \mathrm{~m}$. The subsequent regression at $480 \pm 80$ (Sample 51) is represented by two layers of bivalve shells. Presumably, a short-term sea-level rise occurred during this stage. The third transgression stage is documented in all the sections. Sample $23(240 \pm 80)$ shows its termination. The same age (Sample 22) was obtained from plant debris formed during the successive regression. The sea level at that time was -26 to $-28 \mathrm{~m}$. The last (fourth) transgression stage dates to $150 \pm 80,160 \pm 80$ (sea-level maximum, Samples 21, 49) and $100 \pm 80$ (the end of the transgression, Sample 48; see Fig. 4B). Shells from the depression slope at -16 to $-17 \mathrm{~m}$ were dated at 11,300 \pm 180 (Sample 53), which marks the end of the Higher Khvalyn transgression stage.

\section{Solonchak near Okarem}

The coast in this area is a salt marsh dozens of kilometers long and 6-10 km wide, separated from the sea by a bar. Maps of the year 1912 show that Solonchak was connected with the sea at -24 to $-26 \mathrm{~m}$. Figure 6 shows two selections of Solonchak deposits. The similarity of these sections, which are located rather far apart, is representative of the whole Solonchak sediment layer. They are composed of: 1) sandy loam; 2) alternating layers of shells and sand; and 3) greenish silt.

The paired valves buried in five shell layers (Fig. 6) in the upper part of the deposits reflect five sea-level fluctuations. ${ }^{14} \mathrm{C}$ dates of shells and carbonates (Samples 6, 7, 9, 13, 14 (Table 1)) indicate five transgressions to -25 to $-26 \mathrm{~m}$ and higher, occurring over the past $600-900 \mathrm{yr}$. However, considerable measurement error does not allow us to determine exactly the age of every stage (see Fig. 4C). 


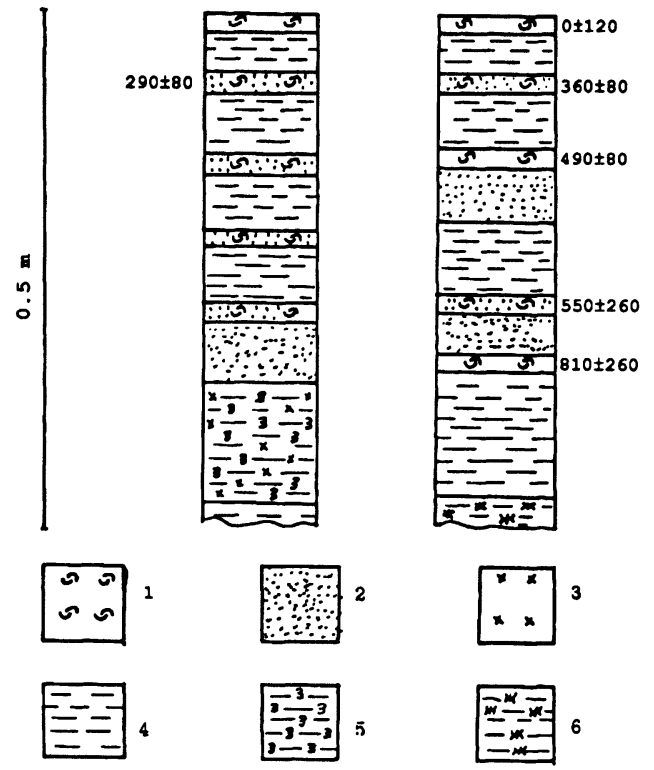

Fig. 6. Two cores of the Solonchak deposit in the Okarem region. 1. bivalve shells; 2 . sand; 3 . gypsum crystals; 4 . sandy loam; 5 . greenish silt; 6 . yellow silt

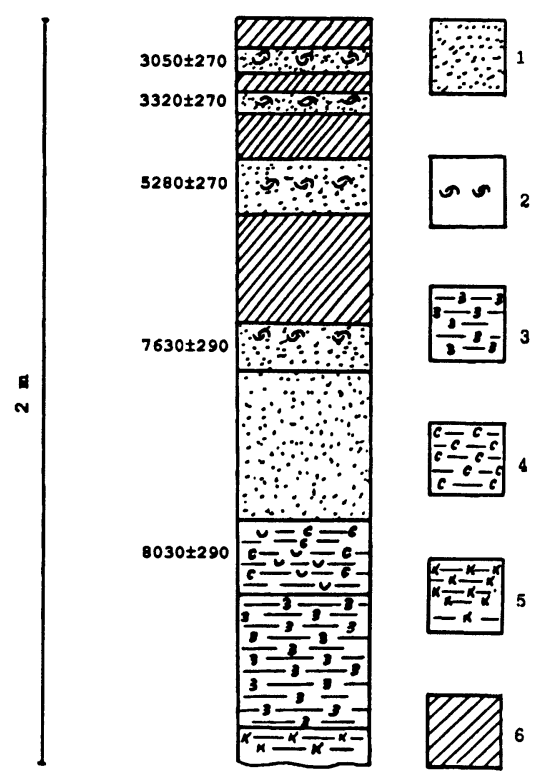

Fig. 7. Profile of the deposits of Kochak Bay. 1. sand; 2. bivalve shells; 3 . greenish silt; 4 . blue silt; 5 . brown silt; 6 . black silt

\section{Kochak Bay Coast}

This area was studied because of its gently sloping shoreline. Samples were collected from Solonchak soil near the boundary of Cardium shells, marking the Novocaspian period. The formation of the Solonchak deposits occurred at the Novocaspian transgression maximum, with sea level rising to $-22 \mathrm{~m}$. Figure 7 shows the profile of the deposit, similar in composition and stratigraphy to the Solonchak deposits of the Ashchi-Sor depression. Layers of greenish, blue, brown and black silts, bivalve shells and evidence of water exchange are similar to those of the Ashchi-Sor depression, but at a higher sea level.

Measured ages of different types of mollusk shells were contradictory; therefore, only carbonate ages are reported here. The first transgression stage dated to $7630 \pm 290$ and $8030 \pm 290$ (3 in Fig. 7; Samples 45 and 46, Table 1). However, the layer of greenish silt was deposited later. Assuming a sedimentation rate of $0.7-1.0 \mathrm{~mm} \mathrm{yr}^{-1}$, established by dating Ashchi-Sor deposits, I calculated that the sea level maximum occurred at 8.3-8 ka ago. The age of the second stage was determined from a single date, $5280 \pm 270$ (Sample 172, Table 1). During the third stage, sea level had two maxima, at $3320 \pm 270$ and $3050 \pm 270$ (Samples 42, 43).

\section{Kara-Bogaz-Gol Bay}

Rikhter (1961) studied basal sediments of this bay to evaluate sea-level fluctuations. At present, the bay is connected with the sea by a narrow strait. The bar in the strait is at $-30.2 \mathrm{~m}$, and is composed of dense limestone. A drop in sea level affects sedimentation in the bay long before the threshold height has been reached. Water depletion causes increased mineralization and settling of salts in the following progression: sand/clay - clay/carbonate - gypsum/carbonate (glauberite) halite. This sequence defines seven sedimentation cycles associated with sea-level fluctuations. 
Figure 8 shows three units of the profile: the terrigenous component, glauberite and halite. Sections I, V and VII represent all three units. During the first cycle, the bay dried up. Sections IV and V had the longest duration and the highest sea level. Evidently, during Stage IV, only a slight rise of sea level occurred. In Stage II deposits, glauberite is not clearly represented; this indicates a short duration. During Stages II and VI, sea level rose less appreciably; the second phase of the series is absent.

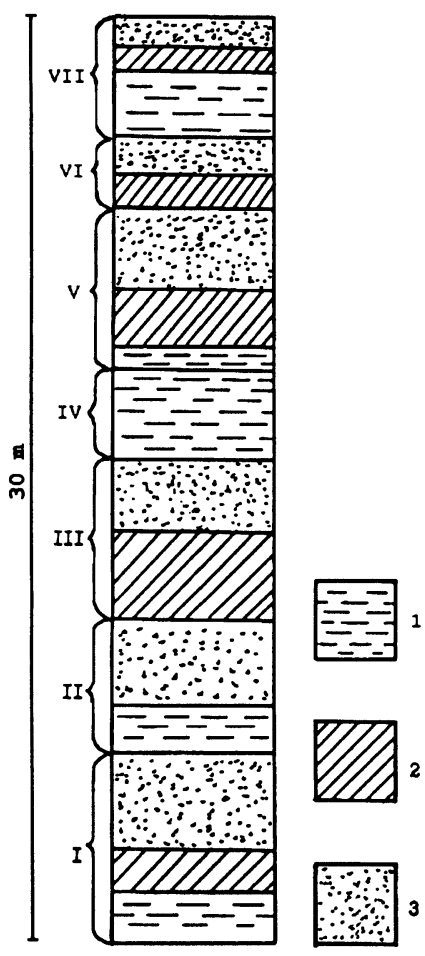

Fig. 8. Profile of the Kara-Bogaz-Gol Bay deposit. 1. terrigenous component; 2. glauberite; 3 . halite; IVII. Cycles of deposition

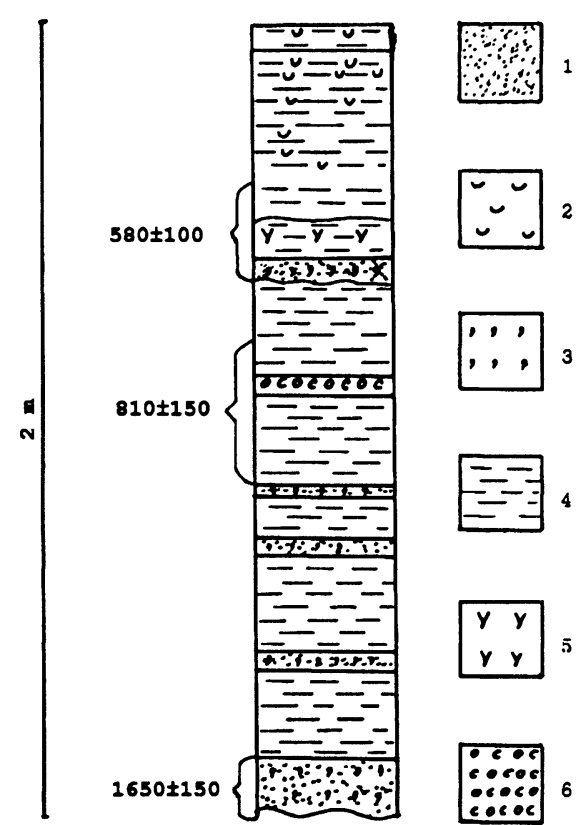

Fig. 9. Profile of the Krasnovodsky Bay deposits. 1. sand; 2. single-valve shells; 3 . shell debris; 4 . silt; 5 . peat; 6. salt

\section{Krasnovodsk Bay, Station 12774}

Krasnovodsk Bay deposits appear as alternating layers of silt and sand with shell detritus (Fig. 9). Two layers confirm the particular sedimentation conditions associated with sea-level decline. Thus, a thin layer of silt was found at a depth of $70 \mathrm{~cm}$, and the deposits at $50 \mathrm{~cm}$ contain plant root debris and fibers. The appearance of vegetation in the bay is associated with the flow of the Amu Daria River via Uzboi during the period of sea-level decline, which, according to archaeological data, occurred at 400-500 BP. The age of the plant debris is $580 \pm 100 \mathrm{BP}$ (Sample 123, Table 1). A date on organic matter (Sample 125) relates the formation of the silt layer to the Derbent regression. Earlier sea-level fluctuations are reflected in the lowermost part of the deposit, in alternating layers of silt and sand. From the sea-level maximum date of $1320 \pm 80$ (Sample 164, the Ashchi-Sor depression, Table 1), before the Derbent regression, and the rate of silt deposition of $0.7 \mathrm{~mm} \mathrm{yr}^{-1}$ for the upper part of the sediment, we can estimate high- and low-level periods. Thus, regressions occurred at 1380,1430,1550 and 1680. The calculated age of 1680 agrees with 
a result for this period from organic matter (1650 \pm 150 ; Sample 127). During these phases, sea level did not fall below $-32 \mathrm{~m}$; during transgression, it did not rise above -29 to $-29.5 \mathrm{~m}$. The level fell to at least $-32 \mathrm{~m}$ during the Derbent regression, and no greater than $-31 \mathrm{~m}$ during the most recent regression (450-500) (Fig. 4D).

\section{Eastern Shelf Margin}

Contemporary sedimentation is absent in this area. Shell layers with gravel suggest a considerably lower sea level for the formation of these deposits. The obvious boundaries in Core 4-86 (Fig. 10) mark four stages of low sea levels, separated by sedimentation pauses that can occur at both low and high sea levels. The age of the first stage (20-22 ka) was determined from shells and carbonates (Samples 203, 223, Table 1). Second-stage deposits are represented by a dense layer of shells. The great quantity of shells allowed us to date separately the whole-bivalved shells and shell debris in columns (4-86) and (5-86) (Samples 227, 209, 202, 205). Good agreement among the dates allows us to estimate the age of the second stage at $11.250-11.5 \mathrm{ka}$. From a carbonate age of 11,700 \pm 270 (Sample 218), I conclude that third-stage deposits originated from the second stage, and were redeposited during transgression.

The age of the last (fourth) stage, determined from shells (Sample 208) is $6950 \pm 170$ and from carbonates (Sample 217), $6900 \pm 270$. The thin deposit layer and low shell content indicate a shorter and smaller sea-level decline during the fourth stage than in the first and second stages.
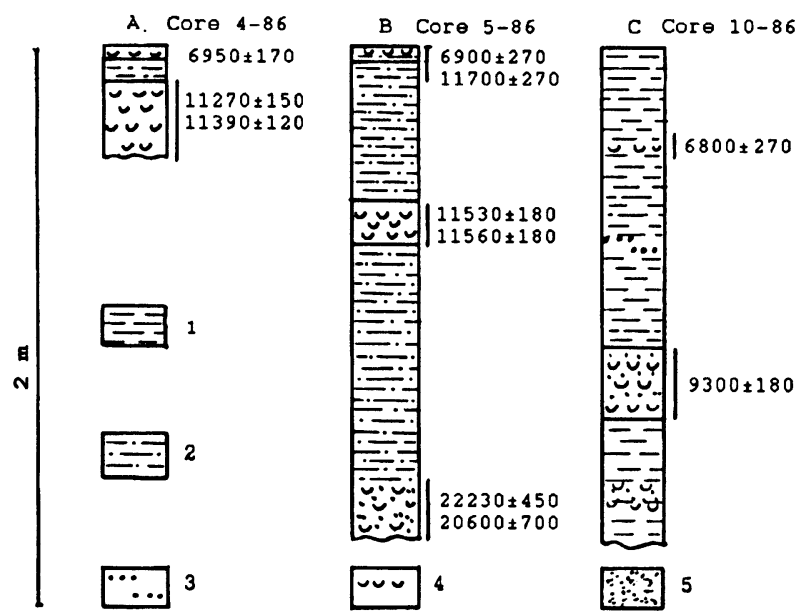

Fig. 10. Profiles of the deposit of the margin of the eastern shelf. A. Core 4-86; B. Core 5-86; C. Core 10-86; 1 . silt, clay; 2. silt, aleuriteclay; 3 . coarse-grained aleurite; 4 . shells; 5 . sand
In Core 10-86 (Fig. 10) only one layer was dated from shells. This layer contains many shells with $<30 \mathrm{~mm}$ alkaline surfaces, marking coastal conditions of deposition. A sharp increase in carbonate content (up to $48-58 \%$ ) in the upper layer of the deposit, as compared to $25 \%$ in the lower ones, suggests that $9300 \pm 180$ (Sample 210) marks the borderline of the Novocaspian period. The next thinner shell layer was dated only from carbonates. The age of 6800 \pm 270 concurs with the dates from Core 4-86 (Fig. 10). The level of the first and second regression stages $(<-130$ $\mathrm{m}$ ) is determined unequivocally, but the level of the second stage $(<-70 \mathrm{~m}) \mathrm{can}$ only be assumed on the basis of faunal analysis.

\section{Discussion}

\section{Sea-Level Fluctuations in Historical Periods}

$A D$ 0-1200. At this time, sea level was presumably undergoing the transition from high to low. From dates of the Agrakhan Spit deposits, sea level at 2060-2260 BP was > $-25 \mathrm{~m}$, and from Krasnovodsk Bay deposits, the level at 1650 was $<-31.5$ to $-32.5 \mathrm{~m}$. This was followed by four fluctuations with lows to -31.5 to $32.5 \mathrm{~m}$ (Fig. 4D) and highs not exceeding $-28 \mathrm{~m}$ (Fig. 4A). The 
most significant decline ( $-33 \mathrm{~m}$ and below) occurred during the Derbent regression, $1200-700$ (Fig. 4B).

$A D$ 1200-1500. During this interval, the Derbent regression was interrupted by a transgression. This rise can be dated more accurately from historical sources (Varuschenko, Varuschenko and Klige 1987). We know that in 1300-1320 the sea level was close to that of the present. It is evident that the lowest sea level during this rise was $-24 \mathrm{~m}$. On the other hand, ${ }^{14} \mathrm{C}$ dating of the peat layer in the Balkhan Sor (Varuschenko, Varuschenko and Klige 1987) shows that during the 5th to 11th centuries, sea level did not rise to $>-24 \mathrm{~m}$. Thus, this level is accepted as the maximum for the period. The next regression, $1400-1500$ (determined from ${ }^{14} \mathrm{C}$ dating), agrees well with historical data. The sea level during this period was -30.5 to $-31.5 \mathrm{~m}$ (Fig. 4B, D).

$A D$ 1500-1850. According to the Agrakhan Spit deposits, this transgression had the highest sea level, $-22 \mathrm{~m}$ (Fig. 4A). In cores from the Ashchi-Sor depression, this stage is separated into two peaks, with a low at $-27.5 \mathrm{~m}$ (Fig. $4 \mathrm{~B}$ ), which is also confirmed by the dating of shore terrace deposits. From historical sources, the $-22-\mathrm{m}$ maximum of the second peak occurred in 1810; this persisted for only two decades. It is unlikely that the upper part of the Agrakhan Spit (3-4 m thick) could have formed over this short interval. Hence, one assumes that sea level during the first peak (1500-1700) also rose to $-22 \mathrm{~m}$, and stayed at this height for a longer time. This contention disagrees with results from the Solonchak deposit near Okaren (Fig. 4C). Presumably, this occurred along with previously determined sea-level rises during $1300-1400$ to $-24 \mathrm{~m}$, and in $1600-1650$ and 1800 -present to $-22 \mathrm{~m}$. Two less significant increases to $-26 \mathrm{~m}$ were indicated by dates from the second layer of shells in Core 3 of the Ashchi-Sor depression and the shell layer in the shore terrace core. Their ages are 450-500 and $130 \pm 60 \mathrm{yr}$, respectively. Extrapolation of these data gives the curve of sea-level fluctuations over the past $2 \mathrm{ka}$ (Fig. 4D). The data of sea-level rise and decline agree with cycles of sedimentation observed in the Kara-Bogaz-Gol Bay.

\section{Holocene Transgressions/Regressions}

The earliest ${ }^{14} \mathrm{C}$ results, 22-20 ka, evidently determine the end of the Yenotayev regression, separating the Upper and Lower Khvalyn periods. Sea level during this period did not rise higher than $-133 \mathrm{~m}$. During the Upper Khvalyn transgression, sea level rose to $0 \mathrm{~m}$ (Varuschenko, Varuschenko and Klige 1987). The end of the Higher Khvalyn transgression was established at 11,300 \pm 180 (Sample 53, from the Ashchi-Sor depression (Fig. 1)). The beginning of the Mangyshlak regression dates to 11,250-11,550 (Samples 201, 202, 205, 209). Sea level at that time was -133 $\mathrm{m}$ or lower. This discrepancy could be associated with a reservoir effect, but overlapping could also be due to statistical error. The calculated rate of sea-level decrease of $300 \mathrm{~mm} \mathrm{yr}^{-1}$ is not wholly unlikely. The end of the Mangyshlak regression dates to $9300 \pm 180$ (Sample 210, shelf edge).

The age of the first and second transgression stages and the two peaks of the third stage are $7600-8300,5280 \pm 270,3320 \pm 270$ and $3050 \pm 270 \mathrm{yr}$ (Samples 46, 45, 172, 43, 42, Kochak Bay coast (Fig. 1)). Nearly the same age of the second (5390 \pm 110$)$ and third (3200-3400) stages was established by dating the deposits exposed by the Turali-Sul'fat Canal (Moscow State University Samples 79, 78, 80, 82) (Rychagov 1974). The section at the base of the Agrakhan Spit, dated at 2800-2060 (Samples 35, 36, 65), probably occurred during the third stage. According to Rychagov (1974), maximum sea level during the first stage was $-20 \mathrm{~m}$, the second, $-21 \mathrm{~m}$, the first peak of the third stage, -22.5 to $22.0 \mathrm{~m}$, and the second peak, -20 to $22 \mathrm{~m}$. The first regression stage was dated to 6800-6950 (Samples 208, 217, 220) and corresponding sea level was ca. $-70 \mathrm{~m}$, obtained 
from dating the deposits of the shelf edge. During all the following regression stages, the sea level was higher than $-70 \mathrm{~m}$.

In view of the above, the 14th to mid-18th centuries should be considered as the period of the fourth transgression stage, preceded by a 13-century regression with a minimum sea level of -34 $\mathrm{m}$. In both cases, however, sea level was constantly changing. It is possible that the other transgressive/regressive stages were, in fact, periods of alternating sea-level rise and fall around a mean value in a given cycle.

\section{CONCLUSION}

It is clear that global climate processes also affected Caspian Sea-level fluctuation, but the degree of influence is yet to be determined. However, we can draw some conclusions based on sea-level fluctuation data. The end of the last glaciation led to the termination of the Upper Khvalyn transgression. The period of maximum insolation corresponds to the Mangyshlak regression. Paleobotanical evidence allows us to differentiate among four periods of Holocene climate change: 1) first postglacial climatic optimum; 2) Iron Age cooling interval; 3) second climatic optimum; 4) Little Ice Age. These periods coincide, respectively, with the first Novocaspian regression, the third transgression stage, the Derbent regression and the fourth transgression stage. A periodicity of $2-2.5 \mathrm{ka}$ is observed.

The average annual air temperature in the northern hemisphere reflects Caspian Sea-level fluctuation. Three cold phases during the Little Ice Age involve three significant sea-level rises, but sea-level decline from 1810-1830 does not correspond to air temperature variation during this period.

Data obtained on Caspian Sea-level fluctuations establish the relation between sea-level fluctuation and global climate change, with higher sea level during cooler periods and lower levels during warmer periods. This correlation can be traced by changes during longer periods $(2-2.5 \mathrm{ka})$ during the Holocene and by short-term variations during the Little Ice Age in the northern hemisphere.

\section{REFERENCES}

Arslanov, Kh. A. and Tertychnaya, T. V. 1983 Content of ${ }^{14} \mathrm{C}$ in Caspian and Black Sea molluscs. Abstracts of the All-Union Workshop, Methods of Isotope Geology. Moscow, GEOHI AN SSSR: 175-177.

Karpytchev, Yu. A. 1987 Study of the Caspian Sea bottom deposits and the sediments of the DnieperBug Liman on the basis of radiocarbon analysis. Vodnye Resursy 10: 147-154.

Lamb, H. H. 1972 Climate: Present, Past and Future, Vol. 1. London, Methuen: $668 \mathrm{p}$.

Olsson, I. U. 1980 Content of ${ }^{14} \mathrm{C}$ in marine mammals from Northern Europe. In Stuiver, M. and Kra, R. S., eds., Proceedings of the 10th International ${ }^{14} \mathrm{C}$ Conference. Radiocarbon 22(3): 662-675.
Rikhter, V. V. 1961 Bottom deposits of the Kara-BogazGol Bay as an indicator of fluctuations of the Caspian Sea level. Bulletin of the MOIP(1): 115-126.

Rychagov, G. I. 1974 Late Pleistocene history of the Caspian Sea. In Complex Studies of the Caspian Sea. Moscow, Publications of the Moscow State University $4: 18-29$.

Varuschenko, S. I., Varuschenko, A. N. and Klige, R. K. 1987 Changes in the Regime of the Caspian Sea and Non-Terminal Water Bodies in Paleotime. Moscow: Nauka, 239 p. 